\title{
Dewey After the End of Art
}

\section{Evaluating the "Hegelian Permanent Deposit" in Dewey's Aesthetics}

\author{
Roberta Dreon \\ Department of Philosophy and Cultural Heritage, Ca' Foscari University, \\ Venice, Italy \\ robdre@unive.it
}

\begin{abstract}
This article explores the significance of Hegel's aesthetic lectures for Dewey's approach to the arts. Although over the last two decades some brilliant studies have been published on the "permanent deposit" of Hegel in Dewey's mature thought, the aesthetic dimension of Dewey's engagement with Hegel's heritage has not yet been investigated.

This inquiry will be developed on a theoretical level as well as on the basis of a recent discovery: in Dewey's Correspondence traces have been found of a lecture on Hegel's Aesthetics delivered in 1891 within a summer school run by a scholar close to the so-called St. Louis Hegelians. Dewey's deep and long-standing acquaintance with Hegel's Aesthetics supports the claim that in his mature book, Art as Experience, he originally appropriated some Hegelian insights. First, Dewey shared Hegel's strong anti-dualistic and anti-autonomistic conception of the arts, resisting post-Kantian sirens that favored instead an interpretation of art as a separate realm from ordinary reality. Second, they basically converged on an idea of the arts as inherently social activities as well as crucial contributions to the shaping of cultures and civilizations, based on the proximity of the arts to the sensitive nature of man. Third, this article argues that an original re-consideration of Hegel's thesis of the so-called "end of art" played a crucial role in the formulation of Dewey's criticism of the arts and of the role of aesthetic experience in contemporary society. The author suggests that we read Dewey's criticism of the removal of fine art "from the scope of the common or community life" (LW 10, 12) in light of Hegel's insight that the experience of the arts as something with which believers or citizens can immediately identify belongs to an irretrievable past.
\end{abstract}




\section{Keywords}

John Dewey - Hegel's Aesthetics - end of art - artistic autonomy

Since the beginning of this century, significant investigations have been conducted into the influence of Hegel on Dewey's mature thought (Shook 2000, Good 2006b, Shook and Good 2010, Calcaterra 2011, Morse 2011). ${ }^{1}$ As a result, it has become clear that Hegel could represent a "permanent deposit" (LW 5: 154) in Dewey's philosophy because he was able to appropriate a non-metaphysical, anti-dualistic and historicist reading of the German thinker within his own original cultural naturalistic approach. More specifically, thanks to James A. Good's inquiries, it has come to light that Dewey's rejection of idealism in the 1890 s should be interpreted as a departure from the British Idealists, from Thomas Hill Green's influence and - as will emerge in this article - from Bernard Bosanquet's dualistic attitude towards the arts. Differently, Dewey grew closer to the St. Louis Hegelians, who carried on a politically progressive reading of Hegel (Good 2005, Morse 2011).

Nonetheless, the aesthetic dimension of Dewey's engagement with Hegel's heritage has not yet been investigated, apart from Thomas Alexander's efforts to compare Dewey's limited sketch of an idealistic aesthetic in his Psychology (EW 2) with the much more complex theory developed in Art as Experience (LW 10) (Alexander 1987: 35-40). Probably, the disagreeable controversy between John Dewey and Benedetto Croce in the last years of their lives also discouraged interpreters from engaging with the Hegelian deposit in Dewey's aesthetics. Another factor was the political stigmatization of Hegel's philosophy in the U.S.A. since the First World War, when the name of the German philosopher became synonymous with the authoritarianism and militarism of the Prussian state (Good 2005: 11-12 and Good 2006a). As is well known, Stephen Pepper and Croce, although for different reasons, criticized Dewey's Art as Experience for implicitly promoting an organic idealistic aesthetics. Croce went so far as to accuse Dewey of plagiarism. Today it is evident that this debate constituted a huge misunderstanding based on some superficial similarities that fatally ignored the very different theoretical contexts in which Dewey and Croce had developed their aesthetic theories. Astonishingly, however,

1 See also Pinkard 2007b and more recently Levine 2015, Sarkela 2017, Testa 2017. 
Dewey's reaction was resentful and unsuccessful, as Thomas Alexander has compellingly showed in his book (Alexander $1987,1-13$ ). ${ }^{2}$

Times are ripe now for investigating the influence of Hegel's aesthetics in Dewey's mature thought. My aim in this article is to explore some of his main original appropriations and re-uses of Hegel's heritage in Art as Experience, by relying on theoretical arguments as well as on some historical reconstructions and a recent rediscovery. Although in his 1934 book Dewey refers only to the translated extract from Hegel's Aesthetics in E.F. Carritt's Philosophy of Beauty (Carritt 1931), his acquaintance with Hegel's aesthetic lessons was a longstanding and profound one. Dewey delivered a lecture on Hegel's aesthetics as far back as in 1891, as emerges from his correspondence with Thomas Davidson, ${ }^{3}$ who organized a Summer School in Glenmore which was closely connected with the circle of the St. Louis Hegelians. In 1891, Dewey took part in the Summer School by delivering a couple of lectures on Hegel: one on his philosophy of the spirit and the other on his aesthetic thought.

In the first section of this article, I will briefly reconstruct the context of Dewey's initial exploration of Hegel's aesthetic lessons, as well as the textual resources on which he could count. In the three following sections, I will develop my investigation on the permanent Hegelian deposit in Dewey's aesthetics on a more theoretical level by arguing that Dewey was able to originally re-appropriate at least three main Hegelian insights.

First, Dewey basically maintained Hegel's deeply anti-dualistic conception of art as a (constitutive) part of this world, against post-Kantian sirens favoring an interpretation of art as a separate realm from the reality we belong to. Dewey's attempt to critically distance himself from Bernard Bosanquet's $A$ History of Aesthetics is evident in his review of the book (EW 4, 189-197) and is basically due to the fact that the British idealist continued to endorse a form of metaphysical dualism.

Second, Dewey, like Hegel, resisted the late Romantic approach to art as primarily an expression of the individual strenuously opposed to traditional habits and norms. Differently, he shared Hegel's view of artistic practices as inherently social as well as deeply intertwined in the shaping of social and political communities (Pinkard 2007a, Pippin 2008). My hypothesis is that Dewey particularly emphasized the proximity of the arts to the sensitive nature of man, insofar as they contribute to societal life through affective, emotional and

2 On the controversy between Benedetto Croce and John Dewey, see also the volume edited by Pio Colonnello and Giuseppe Spadafora 2002.

3 I am referring to a couple of letters from Dewey to Thomas Davidson collected within The Corrispondence of John Dewey. Electronic Edition (1999) and classified as no. 00448 (October $26^{\text {th }}, 1890$ ) and no. 00453 (March $14^{\text {th }}, 1891$ ). 
imaginative resources, as part of a common ethos primarily based on shared sensibilities rather than on rational discourses (Givone 1997).

Finally, I will contend that Dewey's criticism of the museum conception of art and of the state of artistic practices in his time found significant support in a historical-anthropological reading of Hegel's so-called thesis of the end of art. This thesis, I argue, should be connected with the characteristically modern conception of art as an independent and separated field, which marks a serious break with the previous non-autonomist ways of practising the arts in ordinary life contexts (Gadamer 1989 and Gadamer 1993, Pippin 2008). ${ }^{4}$

I am not claiming here that Hegel's aesthetics was the only or main influence on the development of Dewey's aesthetics. His strongly naturalistic approach - based on an anti-deterministic appropriation of Darwin as well as on the disruptive influence exercised by his reading of William James's Principles of Psychology (James 1981) in 1891 - is definitely the most decisive and pervasive factor in the development of his theory of experience, in relation to which Art as Experience must be read. ${ }^{5}$ On the other hand, we should not underestimate the influence of Dewey's political interests on his aesthetic engagement. It must be borne in mind that the publication of most of Dewey's political writings dates back to the period between Experience and Nature and Art as Experience. The role of the arts in the current world is not separate from the broadly political effects they can exercise because of their immediate grasp on the imaginative and sensible nature of man (LW 2:321 and 341, LW 5: 69 and 101). ${ }^{6}$ A further, crucial influence on Dewey's approach to the arts was his strong interest in anthropology, starting from Franz Boas, whose Mind of the Primitive Man (Boas 1911) was an important point of reference for Experience and Nature (Dreon 2012 and Dreon 2018). The anthropologist's distinctive attitude toward the arts as an integral part of the material culture of human communities, continuous with ordinary activities and permeating all everyday life, was close to Dewey's inclusive aesthetics. Finally, Dewey's relationship and friendship with Albert C. Barnes played a significant part in the development of his passion for the arts (see Campeotto, Viale 2018).

4 Crucial inquiries into the emergence of the modern conception of art are Kristeller's account of the emergence of art as a unitary system in the eighteenth century (Kristeller $195^{1}$ and Kristeller 1952) and Larry Shiner's investigations into the previous material conditions that favored the idea of the artist as a genius and the notion of aesthetic experience as a kind of purely formal appreciation abstracted from other modes of engagement with artistic products (Shiner 2001).

5 I have presented a naturalistic reading of Dewey's aesthetics in Dreon 2012 as well as in Dreon 2017.

6 On this point see Westbrook 1991, Dreon 2015, Cometti 2016, Seoane 2018, Skowroński 2018. 
In the light of these clarifications, I think the time has come to make justice of Hegel's permanent deposit in Dewey's approach to human artistic practices, as an important source of inspiration for his view of the arts. ${ }^{7}$

\section{Dewey's 1891 Lecture on Hegel's Aesthetics}

In Art as Experience Dewey makes explicit reference to Hegel just a couple of times. Within the "Checklist of Dewey's References" the editors include Hegel's Aesthetics, in the translation by E.F. Carritt, from his comprehensive anthology Philosophies of Beauty from Socrates to Robert Bridges: Being the Sources of Aesthetic Theory, published by Oxford University Press in 1931 (Carritt 1931). ${ }^{8}$ This deals with a very limited number of passages from Hegel's aesthetics lectures, arbitrarily selected by Carritt, who had been fellow and lecturer at the University of Oxford; he had also spent one year as visiting professor at the University of Michigan (Skelton 2016). In his short preface to his translation, Carritt makes at least one claim that might be important for Dewey's likely interests in Hegel's aesthetics: he argues that Hegel "denied the distinction between experience and ultimate reality, or rather asserted that this distinction, like every other, arises within reality and within experience" (Carritt 1931, 159). This position might be significant for Dewey because it opposes the dualistic interpretation endorsed by Bernard Bosanquet, as I will explain in the next section. In any case, these pages in themselves do not seem to provide sufficient evidence to argue in favor of an influence from, or an appropriation of, Hegelian issues in Dewey's mature aesthetics.

Nonetheless, this is just a part of a more complex story, because some important documents testify to the fact that Dewey's knowledge of Hegel's aesthetic lessons was a long-standing and enduring one. In his correspondence, there are a couple of letters Dewey sent to Thomas Davidson in October 1890

7 I understand Larry Hickman and Thomas Alexander's worries (in Hickman 2008 and Alexander 2008), but I do not support a form of interpretative reductionism - as if Dewey's aesthetics were nothing else than Hegel's philosophy of art expressed through a different lexicon. On the contrary, my interest lies in exploring the rich and nuanced web of influences that nourished Dewey's investigations into the role of the aesthetics in human experience and the functions of artistic practices in human civilizations.

8 Dewey does not refer to the complete English translation of Hotho's edition of Hegel's aesthetic lectures published by F.B.P. Osmaston in 1920 (Hegel 1920), that is almost 30 years after his lecture on Hegel's Aesthetics, but years before the publication of Art as Experience. Another English translation was later produced by T.M. Knox in 1975 (Hegel 1975). 
and in March $1891,{ }^{9}$ mentioning two lectures he was going to deliver in Glenmore, one on Hegel's Aesthetic and another one on Hegel's Philosophy of Spirit. The latter is probably a first draft of his 1897 Lecture, now published by Shook and Good (Shook and Good 2010), where a few final pages are devoted to the Hegel's doctrine of the three stages of the artistic idea (symbolic, classic, and romantic). ${ }^{10}$ In John Dewey's Life and Works Chronology, ${ }^{11}$ Barbara Levine records two lectures given at Glenmore in ${ }^{1891}$. The Scottish Review ${ }^{12}$ confirms that Dewey delivered two lectures on Hegel at a Summer School of Philosophy running from August the $3^{\text {rd }}$ to August the $8^{\text {th}}$ : one on Hegel's philosophy of spirit on Monday and one on his aesthetics on Wednesday.

Unfortunately, there are no notes either by Dewey himself or by one of the students attending the lecture in the Special Collections Research Center at Morris Library in Carbondale. Nonetheless, there are some important elements that can be derived from what material is available.

The first element is that Dewey held the lectures in question within a Summer School organized by Thomas Davidson, who, as stated by James A. Good, ${ }^{13}$ was one of the main figures among the so-called St. Louis Hegelians. This circle of thinkers generally endorsed a politically progressive reading of Hegel's philosophy, mediated by their focus on Rosenkranz's biography (Rosenkranz 1844) and were interested in finding a way to accomplish the ideals of political independence and democracy advocated by the American Civil War as well as by the French Revolution, while avoiding the negative consequences that had culminated in the Reign of Terror (Good 2006b: 74). Dewey was to grow closer to that group, while distancing himself from the British Neo-Hegelians, Thomas Hill Green and particularly - and most crucially for the purpose of this article Bernard Bosanquet.

9 See note 5 above: the two letters from Dewey to Davidson are classified as no. o0448 (October $\left.26^{\text {th }}, 1890\right)$ and no. 00453 (March $\left.14^{\text {th }}, 1891\right)$ within The Correspondence of John Dewey. Electronic Edition (1999).

10 The 1897 Chicago Lectures on Hegel's Philosophy of the Spirit have been edited by John R. Shook and James A. Good in Shook, Good 2010. The references to artistic development are on pp. 171-174.

11 The Chronology of John Dewey's Life and Work, compiled by Barbara Levine, is included within the third volume of Dewey's Correspondence. Electronic Edition.

12 Scottish Review, 19/1892, pp. 107-108.

13 "Davidson was an active member of the St. Louis Philosophical Society from 1868 to 1875. In 1889 he established the Glenmore Summer School of the Culture Sciences in the Adirondack Mountains of upstate New York at which Harris, Dewey, Royce and Santayana all lectured for several summers. Harris built a summer vacation cottage for his family at Glenmore. Dewey bought land across the road from Glenmore where he too built a summer vacation cottage" (Good 2005, 21). See also Good 2006, 63-64. 
A second important element is represented by the list of books that Dewey recommends to Thomas Davidson as useful references for his seminar on Hegel's Aesthetics in a letter to him from March 1891.

First of all, Dewey mentions Bernard Bosanquet's complete translation of the Introduction to Hegel's Aesthetics, included in Hotho's historical edition of his aesthetic lectures (Bosanquet 1886). Furthermore, Dewey recommends John Steinfort Kedney's book Hegel's Aesthetics. A Critical Exposition (Kedney 1885), as well as V.M.M. Bryant's The Philosophy of Art: Being the Second Part of Hegel's Aesthetics (Bryant 1879). ${ }^{14}$

It cannot be excluded that Dewey read Hegel's Aesthetics directly and entirely in German but, for sure, he read Bernard Bosanquet's prefatory essay to his English translation, whose position was evident from the very title, On the True Conception of Another World. Bosanquet's interpretation of Hegel's theory of art basically rested on a dualistic and almost Kantian attitude, still opposing the sensuous world to the spiritual or "supra-sensuous" one, although the author argued that the distinction had to be maintained within the Spirit. "This world and the other world are continuous and inseparable", says Bosanquet, "and all men must live in some degree for both. But the completion of the Noumenal world, and the apprehension of its reality and completeness, is the tusk by fulfilling which humanity advances" (Bosanquet 1886, XXII-XXIII).

Differently from Bosanquet, William M. Bryant centered his interpretation of Hegel's aesthetics on art understood as the history of the human spirit (Bryant $1879, \mathrm{X}-\mathrm{XI}$ ). His anti-dualistic approach is confirmed by the conclusion of his introduction to the translation he made mainly from the French edition by Charles Bérnard, although consulting the German edition by Hotho any time he was in doubt about the French translation. Bryant was one of the St. Louis Hegelians and he shared their historicist and humanistic reading of Hegel's philosophy.

Finally, John Steinfort Kedney proposed a kind of mixed work, consisting partly in a condensed version of Hegel's lectures, and partly in an "original disquisition" (Kedney 1885, VI). He seems to adopt a historical, humanistic reading of Hegel's Aesthetics. By focusing on the development of "the Protean spirit of man" (Kedney 1885, 149), he asks about the future of art: "The very interesting question would now arise, What is the future of Art? Is there a new stadium probable, or even possible? [..] the answer to this inquiry must depend upon our ability to forecast the philosophic history of the human race, or rather the form of its religious belief" (Kedney 1885, 148).

14 Dewey also recommends Edward Caird's Hegel (Caird 1883) as a reference for his lecture on Hegel's Philosophy of Spirit. 
So, where could we situate Dewey in relation to these different approaches to Hegel's philosophy of art, considering that we lack the original notes by the American philosopher? It should be observed that Dewey developed his interest in Hegel's aesthetic lessons in the 189os, that is in a period when, following his reading of William James's Principles of Psychology in 1891, his philosophical position changed substantially: Dewey's essay on the reflex arc concept and those on emotions date back to 1896 (EW 4 and EW 5) and are commonly considered to be a crucial turning point by scholars (Tiles 1999, Alexander 2008).

My contention is that Dewey's reading of Hegel's philosophy of art supports the thesis that in that period he decisively distanced himself from the British Neo-Hegelians also from an aesthetic point of view (Shook and Good 2010). By favoring an immanentist, humanistic and historicist reading of Hegel's Aesthetics, Dewey was rejecting the dualistic, almost Kantian-Platonic approach to Hegel even on the aesthetic level. ${ }^{15}$ Dewey clearly opposed the kind of dualism between an alleged realm of art and everyday reality that still characterized Bosanquet's philosophical position. This topic will be the subject of the next section.

\section{An Art of this World}

While being a scholar of Thomas Hill Green's thought, Dewey criticized the British neo-Hegelians at a very early stage on the basis of an immanentist reading of Hegel. William A. Good maintains that in a couple of early essays ${ }^{16}$ Dewey criticized these philosophers for adopting a kind of Kantian stance, insofar as they tried to explain experience through elements conceived as external and transcending experience itself - a feature that will prove to be a decisive component of Dewey's naturalism in his mature thought (Margolis 2002). In 1892 - that is one year after his lecture on Hegel's Aesthetics - Dewey wrote an essay concerning Green's Theory of the Moral Motive (EW 3) in which he "referred to Green as a neo-Kantian because he transformed Hegel's immanent absolute into a transcendental absolute for the same reason that Kant postulated a noumenal realm and the categorical imperative" (Good 2005, 15).

15 This dualistic reading of Kant's aesthetics should be formulated in far more nuanced terms if the complex text of his third Critique is taken into account. On this subject see Emilio Garroni's and Pietro Montani's interpretations (Garroni 1976, Montani 1996). Differently, this approach is justified if we consider the Wirkungsgeshichte of Kant's aesthetics, with reference to Schiller and, above all, to Arthur Schopenhauer (Clegg 1994).

16 Precisely "The Psychological Standpoint" and "Psychology as Philosophic Method", both of them in EW 1. 
It seems that Dewey adopted a similarly critical stance in the aesthetic field when reviewing a book by Bernard Bosanquet, another outstanding figure among the British neo-Hegelians, together with Green. In discussing Bosanquet's History of Aesthetics, Dewey begins by expressing appreciation for his idea that "the central matter to be elucidated is the value of beauty for human life" (EW 4, 189). Dewey particularly values Bosanquet's interest in the British aesthetics of Ruskin and Morris, insofar as they insisted "upon the place of the individual workman in all art, the necessity that art be a genuine expression of the joy of the worker in his work, and the consequent greater attention to the minor arts, so called" (EW 4, 196). This passage seems to foreshadow Dewey's mature tendency to blur and problematize the distinction between fine arts and popular arts (Shusterman 200o), while also disputing the separation of work from enjoyment (see MW 14, 86, LW 10, 14-15 also Mead 1926).

However, the second part of Dewey's review leaves room for a strong criticism of Bosanquet's aesthetic dualism. The critical point is that Bosanquet assumes that there is "a fixed distinction between the realm of art and that of commonplace reality" (EW 4, 196), whereas Dewey thinks that this postulation should be seriously problematized because this problem lies "at the very heart of aesthetics" (EW 4, 196).

Dewey was not alone in stating that the dichotomy between an alleged merely spiritual realm of art and the ordinary world is at the heart of aesthetics. In the immediate wake of Kant, and against the background of an increasing demand for artistic autonomy, a trend towards the opposition between art and reality had emerged in various ways. Hans-Georg Gadamer famously claimed that a sharp distinction between art and non-art began to rise with Kant's characterization of the aesthetic judgment as something foreign to any cognitive pretension, as well as with the complete removal of all aesthetic aspects from moral judgment. According to Gadamer (Gadamer 1960), a decisive move in that direction had come with Schiller's contrast between art as an ideal realm and empirical reality, although Gadamer's thesis oversimplifies Schiller's position (see Marcuse 1966, 172 and ff.). Schopenhauer (Schopenhauer 2008) definitely dichotomized art and the everyday world: the arts and music, more specifically, came to be considered a metaphysical organon, capable of grasping a more authentic truth lying beyond the alleged realm of mere appearances. According to Clegg, Schopenhauer inserted a neo-Platonic element within German Idealism (Clegg 1994). Many years later, a similar kind of ontological and epistemological dualism remained at the core of abstraction in visual arts (Poggi 2014), as witnessed by Kandinsky's famous essay on The Spiritual in Art (Kandinsky 1977).

Hegel's approach to the arts was the opposite of this kind of dualism, as Dewey realized. Hegel basically denied artistic autonomy, by considering the 
arts social institutions that were continuous with religious and civic institutions (Pippin 2008, 394-395). Nonetheless, there have been attempts in the past to interpret even Hegel's Aesthetic through dualistic lenses, as can be seen in the case of the British neo-Hegelians and especially of Bernard Bosanquet.

A charge of aesthetic Platonism could be leveled against Hegel because of his famous definition of art as the "sensible appearance of the Idea", which could be interpreted as assuming a kind of Platonic prejudice: art would be merely the shadow of a much clearer Idea because the Idea of Beauty could find only limited expression in its historical realizations (Gethmann-Siefert 1984). The definition was slippery for sure, even though it did not prevent Dewey from adopting an immanentist reading of Hegel's Aesthetics. Anyway, as Anne-Marie Gethmann Siefert's philological work has demonstrated, this sentence never occur in Hegel's notebooks by Hegel or in his students' writings: it is an interpolation by Heinrich Gustav Hotho, the famous editor of Hegel's Aesthetics, who issued a volume that Hegel had never actually written, in order to safeguard his thought after his death. ${ }^{17}$

Dewey clearly resisted any dualistic temptation in dealing with the arts, and a basically continuistic attitude characterized the early stages of his thought as well as his mature philosophical attitude. His approach to the issue remained basically the same in his review of Bosanquet's book and in Art as Experience, which was published forty years later. It is worth quoting a passage from the latter work in full:

Instead of accounting for Plato's treatment of art by saying that he failed to distinguish between common reality and the artistic image, it seems to me more philosophical as well as more historical to say that man was then becoming conscious of ideas (principles of action) wider than those expressed in previous civilization; ideas demanding therefore new forms of embodiment and calling for new art, ideas which since they had not found embodiment for themselves appeared at the time to be hostile to all embodiment and thus to all art. The growing up of this distinction between commonplace reality and art seems to be due to just those historical periods when man has become aware of new principles of action just enough to condemn old action, but not sufficiently to secure expression for them. Commonplace reality, in other words, is simply the material

17 In any case, this expression too could and should be interpreted as representing art as the sphere in which the spirit is presented or manifested within a sensible body, insofar as appearance is regarded as the positive process of self-manifestation or becoming conscious to itself of the spirit, rather than as something negative and opposed to an allegedly more authentic reality. 
which art has not yet conquered, which has not yet become a plastic medium of expression. Such a conception, indeed, is in line with Mr. Bosanquet's remarks about the future of art, when he says that in spite of the present apparent interruption of the art tradition, in spite of the fact that the discord of life has now cut deeper than ever before, we may feel sure that the human mind will find a way to resolve this discord and "the way to satisfy its imperious need for beauty. (EW 4, 196-197)

Dewey does not deny the presence of tensions, even dramatic ones, between the innovative ideas (understood as principles of action) emerging within current societies and the lack of adequate means to express them and lend them an artistic form. However, Dewey believes that the arising of tensions should be explained from the point of view of human historical and cultural development. In this, he comes closer to Hegel and rejects Green and Bosanquet's neoKantian or dualistic reading of the philosopher. In Art as Experience Dewey states that a philosophy of art must ask itself what life functions are exercised by artistic practices within a specific socio-cultural context, and whether, how and why they are fulfilled (LW 10, 17). In Ch. 14, he speaks of the present condition of the arts within community life as being characterized by "widespread disruption" (LW 10, 340), meaning that new issues and norms of action are emerging - new ways of perceiving and considering the environment, to which we are not yet ready to give an adequate artistic form in order to satisfy our needs.

These problems are real, for Dewey, but they become an obstacle - first of all on the social and political level, but also on the metaphysical one - when they give rise to dogmatic oppositions between an allegedly separate realm of "ethereal things" and everyday life conditions.

It is now time to turn to the beginning of Art as Experience.

When artistic objects are separated from both conditions of origin and operation in experience, a wall is built around them that renders almost opaque their general significance, with which esthetic theory deals. Art is remitted to a separate realm, where it is cut off from that association with the materials and aims of every other form of human effort, undergoing, and achievement. A primary task is thus imposed upon one who undertakes to write upon the philosophy of the fine arts. This task is to restore continuity between the refined and intensified forms of experience that are works of art and the everyday events, doings, and sufferings that are universally recognized to constitute experience. Mountain peaks do not float unsupported; they do not even just rest upon the earth. They are the 
earth in one of its manifest operations. It is the business of those who are concerned with the theory of the earth, geographers and geologists, to make this fact evident in its various implications. The theorist who would deal philosophically with fine art has a like task to accomplish. (LW 10: $9^{-10)}$

I have quoted this long passage because I believe that new light can now be shed on the criticism that Dewey levels against the "compartmental conception" (LW 10, 14) of art, which isolates artistic products from the actual conditions of human life they have emerged from, as well as from the consequences these products can have on ordinary human experience. Of course, a primary drive for this criticism is constituted by Dewey's naturalistic stance, which requires a serious reframing of human experience as something basically concerned with the life of organisms within an environment. The roots of aesthetic experience are not to be found in an insulated form of purely aesthetic contemplation, but in the structural exposure of the human animal to its natural and naturally social environment: "Nature", Dewey says, "is kind and hateful, bland and morose, irritating and comforting" (LW 10, 21) because humans are vulnerable beings, whose life depends on interaction with an adverse or welcoming surrounding. Artistic practices, as well as more emphatically aesthetic experiences, are to be understood as continuous with these "biological commonplaces" (LW 10, 20), as the refinement and enhancement of consummatory phases within organic-environmental interactions (LW 10, Ch. 3). The naturalistic issue remains the strongest impulse in Dewey's conception of the arts and their roles in human forms of life, even if this is not the focus of the present article.

Nonetheless, I would argue that Dewey's original interest in an immanentist reading of Hegel's aesthetics is still perceivable in the background. Hegel's famous image from Phenomenology of Spirit seems to resonate in Dewey's criticism of the conception of artworks as "ethereal things" separated from the natural condition of life: works of art are like fruits that have been cut off from their tree, as well as from the sunlight and soil that had been nourishing them. Our enjoyment of works of art is now compared to the mere wiping off of some drops of rain or specks of dust from the fruits (Hegel 2018, 432). ${ }^{18}$ In his turn,

18 Here is the complete passage from Hegel's Phenomenology: "The statuary columns are now corpses from which the animating soul has escaped, just as the hymns are now words from which belief has fled. The tables of the gods are without spiritual food and drink, and consciousness does not receive back from its games and festivals the joyful unity of itself with the essence. The works of the muse lack the force of the spirit which, from out of the crushing of the gods and of man, has engendered its certainty of itself. They are 
Dewey states that the "museum conception of art" (LW 10,12) prevents us from realizing that, for example, the Parthenon was not primary conceived as a work of art by the ancient Athenians but rather as a kind of celebration of their civic religion. For Hegel, the arts were essential products of human development as well as structural media enabling a development of the human spirit, but the process was understood as being historical, subject to change, and exposed to crisis and ruptures. This issue, I contend, should be connected with Hegel's thesis on the so-called end of art, which Dewey was able to appropriate and redevelop in an anti-metaphysical vein - an issue that will be the focus of the last part of this essay.

For the moment, it might be interesting to end this section by considering what reasons lie at the basis of works of art as "ethereal things", separated from ordinary things and events, according to Dewey. First of all, he focuses on the political and economic conditions of life characterizing his (and our) age: on nationalism, with its search for a strong super-individual identity, as well as on rapid industrialization and the consequent rigid division of work and compartimentalization of life (as well as of works of art). Nonetheless, this is only part of the picture: the moral opposition between the spiritual and the material, the ideal and the empirical, the body and the soul is considered the root out of which metaphysical dualism has emerged and nourished even the politically regressive conception of works of art as something belonging to a separate

now what they are for us - beautiful fruit broken off from the tree, a friendly fate passing those works on to us as a gift, in the way a young girl might present that fruit; the actual life in which that fruit existed no longer exists, nor does the tree that bore them, nor the earth and the elements that constituted their substance, nor the climate that constituted their determinateness, nor the alternation of the seasons that governed the process of their coming-to-be. - With those works of art, fate does not give us their world, does not give us the spring and summer of the ethical life in which they bloomed and ripened; rather, it gives us solely the veiled remembrance of this actuality. - In our enjoyment of them, our doing is thus not that of the divine worship, which would result in its complete truth filling out our consciousness. Rather, our doing is external, which wipes off some drop of rain or speck of dust from these fruits, and, in place of the inner elements of the actuality of the ethical that surround it, create it, and give spirit to it, we erect the extensive framework of the dead elements of their outward existence, their language, their history,etc., not in order to live in those elements ourselves, but only to represent them as they were in themselves" (Hegel 2018, 432). James A. Good states that Dewey read the Phenomenology of the Spirit on his own in the years he was distancing himself from Green and the British neo-Hegelians and growing closer to the group of the St. Louis Hegelians (Good 2006, 117). The latter generally privileged the Phenomenology, which they read directly in German. Good also notes: "No doubt Davidson, Harris, Dewey, and Royce spent many evenings around the campfire at Glenmore discussing the intricacies of Hegel's Phenomenology" (Good 2006, 157). 
realm, a realm better and higher than ordinary reality. It is not difficult to see in this last reason considered by Dewey the weight of his Puritan education, from which he originally tried to escape by relying on Hegel's thought, as he famously declared in his autobiographical intellectual sketch, From Absolutism to Experimentalism, in 1930 (LW 5). ${ }^{19}$

\section{Art and Civilization}

When compared to the aesthetics of the genius that constituted a prevailing trend in Hegel's time, the Hegelian philosophy of art appears to mark a break, as it considers art something primarily embedded in human civilization and embodying the social ethos of human communities. Hegel stands at the opposite end of the spectrum even in relation to Kant's stress on the freedom of the artist from any pre-established rule (Kant 200o, $\S 46) .{ }^{20}$ By contrast, Hegel is interested in weaving the narrative of the trans-individual struggle for the freedom of the spirit from merely external constraints. This is the tale of humans becoming aware of what it means to be human through art, religion and philosophy: the journey human beings make to become what they are by acting as free agents (Pinkard 2007, 8-9). For sure, from a metaphysical point of view, the sensible matter through which the spirit becomes aware of itself in art is an obstacle to be overcome. However, art also constitutes a privileged position from an anthropological point of view, because according to Hegel its sensuous character - its being "so closely akin and so friendly to sense" (Bonsanquet 1886, p. 17) - represents the moment when the spirit is closest to our embodied nature.

Dewey could find some support in his interpretation of Hegel's Aesthetic as a text primarily dealing with the development of the spirit of man or humanity, rather than an individual form of expression, in most of the literature he referred to both in Art as Experience and in his letter to Thomas Davidson about his 1891 lecture. Carritt explicitly deals with the dialectical development of art and with the narrative of the human spirit becoming practically and theoretically aware of itself in his introduction to his selected translation of Hegel's Aesthetics (Carritt, 1931). Kedney emphasizes the history of the spirit as

19 We should bear in mind that only one year later Dewey held a series of ten lectures at Harvard University on the philosophy of art, which could be considered to lie at the origin of Art as Experience (LW 10: 7).

20 For sure, Kant's conception of the genius is more nuanced than the Romantic one, as acknowledged by Gadamer in Gadamer 1989, 47 and ff. For a balanced account of the relationship between the Kantian concept of genius and rules, see Proulx 2011. 
"the history of the human race" or "of the protean spirit of man" (Kedney 1885, pp. 148 and 149). Even Bryant characterizes artworks as different "artistic efforts" to give form to the human spirit and mind (Bryant 1879, X-XI). In sum, all of these interpreters generally favoured a historical-humanist reading of Hegel's history of the spirit through different artistic phases - although it cannot be denied that Hegel's philosophy of art also has a metaphysical or systematic meaning (D'Angelo 2000).

In any case, beyond this potential inputs that may have had an impact on Dewey's reading of Hegel's theory of art, in Art as Experience - especially in the last chapter - Dewey de facto strongly emphasizes both of the above mentioned aspects characterizing Hegel's attitude. On the one hand, Dewey highlights the inherently social character of the arts, their having to do with the evolving spirit of humanity; on the other hand, he stresses their capacity to embody a common culture as well as shared customs and norms through their sensible nature, namely by "affecting the imagination and the emotions of men" (LW 10, 346). The arts are "saturated" (LW 10, 329) with customary habits and shared norms of life that impinge on our sensibility, rather than being the product of a consciously rational choice. ${ }^{21}$ "The material of esthetic experience in being human - human in connection with the nature of which it is a part is social" (LW 10, 329). There is an important convergence between Hegel and Dewey when it comes to the idea that the arts are primarily a means to shape and share common cultures and civilizations rather than the expression of privileged individuals, as increasingly suggested by the rhetoric of the romantic artist. Consequently, it is even more interesting that in the first pages of the chapter entitled "Art and Civilization" Dewey speaks about "the function of the arts in older civilization" ( $\mathrm{LW} \mathrm{10,330).} \mathrm{It} \mathrm{could} \mathrm{even} \mathrm{be} \mathrm{said} \mathrm{that,} \mathrm{thanks} \mathrm{to}$ his acquaintance with anthropological research, he adopts a more radical position than Hegel's with reference to the arts and societal life: he considers not only sculptures, paintings or the poetry as primary expressions of the life of a community, but also pottery, rites of mourning, war and harvest dances, ceremonial songs and ritual feasts (LW 10, 330), i.e. the wide variety of broadly artistic practices out of which the so-called fine arts can emerge. ${ }^{22}$ In other words, while the arts are interpreted both as the cultural products of a civilization and as the means by which the members of a community shape and share their culture, Dewey claims that it should be taken into account that "popular

21 See also Pippin 2007, 402, who speaks about "enliving" as a "crucial element in the conditions for the possibilities of any norm's grip on those bound to it".

22 On this point there is clear evidence of the influence of cultural anthropology on Dewey's attitude towards artistic behaviors within ordinary life, as I have argued in Dreon 2012 and Dreon 2018. 
arts of song, dance, story-telling, and picture-making, outside of officially sanctioned and directed arts" (LW 10, 156-157) already operate within a form of life and contribute to forge it from within. ${ }^{23}$

In any case, when reading "Art and Civilization" in comparison to Hegel's Aesthetics, a couple of aspects stand out. The first consists in the stress on the capacity of artistic practices in past civilizations to exercise vital functions within a community life. In past cultures and societies, artistic practices answered men's "needs" and wants (LW 10, 330) - the human needs to celebrate events, to gather energies and intensify them when facing special circumstances, to nourish the sense of belonging, to introduce and share social values (LW 10, 330-331). The arts could also satisfy "aesthetic hunger" (LW 10, 330): they made it possible for human beings to enjoy fuller and more intense exchanges with the natural and naturally social environment.

The second aspect regards Dewey's emphasis on the limits of labeling such practices as "art" and "works of art". Dewey says that "These objects and acts were much more than works of art to the worshipers who gathered in the temple. They were much less works of art to them than they are today to believers and unbelievers" (LW 10, 332). Dewey was highlighting that those practices were deeply embedded within specific forms of life, they were continuous with other ordinary practices (i.e., the arranging of dishes and of the gathering place was not separate from the act of eating together) and extraordinary situations (i.e., dancing and singing to propitiate a good harvest or a war victory were perceived as integral parts of the processes of cultivation and of fighting against an enemy). Paraphrasing Hegel's words, medieval believers did not consider the statues of the Madonna and the saints as independent works of art to be aesthetically appreciated: on the contrary, they kneeled and venerated them, and their enjoyment of the sweet face of God's mother was an integral part of their fervent pray. To quote another great interpreter of Hegel's anti-autonomistic stance toward the arts,

At any rate, it cannot be doubted that the great ages in the history of art were those in which people without any aesthetic consciousness and without our concept of 'art' surrounded themselves with creations whose function in religious or secular life could be understood by everyone and which gave no one solely aesthetic pleasure. (Gadamer 1975, 69). ${ }^{24}$

\footnotetext{
23 In this context, Dewey makes an explicit critical reference to Hegel, when arguing that symbolic art - that is, art related to priestly and royal sanction, according to Dewey's interpretation - was the first stage in art (LW 10, 156). 
Of course, Dewey's naturalistic account of the arts was the main support for his thesis on the continuity of the arts with the basic features of experience. His great interest in anthropological inquiries, starting from Franz Boas' research at Columbia (where the latter was a colleague of Dewey's), was also very significant for the development of his attitude. Nonetheless, I believed that an original endorsement of Hegel's aversion to deal with art as a separate, independent realm (see Pippin 2008) played an important role, especially as a crucial criterion for evaluating the current state of the arts.

\section{The End of Art and Artistic Autonomy}

Recent scholarship on Hegel has emphasized that his thesis on the so-called "end of art" represents a crucial aspect of his philosophy of art, not least in the light of the notebooks edited by Anne-Marie Gethmann-Siefert and her colleagues (see D'Angelo 2007, XXXI). As is well known, Hegel did not speak of the end or the death of art at all, but of its alleged belonging to the past. In Bernard Bosanquet's translation of Hegel's Introduction to his Aesthetics - taken from Hotho's edition and mentioned by Dewey as a primary source for his 1891 lecture on Hegel's Aesthetics - the German philosopher makes the strong claim that "In all these respects art is, and remains for us, on the side of its highest destiny, a thing of the past" (Bosanquet 1886, 19).

At the basis of this radical claim there are, of course, two intertwined issues. First of all, there is the systematic, metaphysical significance of the end of art, meaning essentially that art belongs to the past of the Spirit because of its sensible and consequently limited way of letting the Absolute becoming aware of itself. The sensible channel still represents an obstacle and a limit from which the Spirit has to free himself in order to become $A b$-solutus, literally without any bond that could limit its infinite power. This point could probably be considered the most remote from Dewey's naturalistic stance, because it involves the systematic metaphysical assumption that the movement of the Spirit discovers that Nature is nothing more than the product of the Spirit itself. $^{25}$

25 In it in such terms that I understand Thomas Alexander's emphasis on the difference between Hegel's rationalism and Dewey's criticism of the intellectual fallacy, according to which experience is far from reducible to cognition, reason or the spirit (Alexander 2008, 566). According to Dewey, the arts are primarily animated and nourished by organic life depending as they do on a natural as well as naturally social environment - rather than by the spirit; and the spirit (if this word could still be used in relation to Dewey's philosophy to deal with the concept of mind) is itself an emergent mode of organic-environmental interaction. 
The second line of interpretation is an anthropological-historical one, meaning that art or, better, certain ways of experiencing art are by now part of the human past (Gadamer 1985). Hegel stresses the pronoun "us" again and again when speaking about the art belonging to our past, thereby confirming both the prevalent orientation of many current Hegelian scholars (see Morse 2011, 258) and the originally historical focus on Hegel of the St. Louis Hegelians. I would contend that Dewey was struck by this idea of art as something belonging to the past of humanity and originally appropriated it when considering the present conditions of the arts.

Let's focus on a couple of crucial passages taken from Bosanquet's translation.

The peculiar mode to which artistic production and works of art belong no longer satisfies our supreme need. We are above the level at which works of art can be venerated as divine, and actually worshipped; the impression which they make is of a more considerate kind, and the feelings which they stir within us require a higher test and a further confirmation. Thought and reflection have taken their flight above fine art. (Bosanquet 1886, 17)

[...] art no longer affords that satisfaction of spiritual wants which earlier epochs and peoples have sought therein, and have found therein only; a satisfaction which, at all events on the religious side, was most intimately and profoundly connected with art. The beautiful days of Greek art, and the golden time of the later middle ages are gone by. The reflective culture of our life of to-day, makes it a necessity for us, in respect of our will no less than of our judgment, to adhere to general points of view, and to regulate particular matters according to them, so that general forms, laws, duties, rights, maxims arc what have validity as grounds of determination and are the chief regulative force. But what is required for artistic interest as for artistic production is, speaking generally, a living creation, in which the universal is not present as law and maxim, but acts as if one with the mood and the feelings, just as, in the imagination, the universal and rational is contained only as brought into unity with a concrete sensuous phenomenon. Therefore, our present in its universal condition is not favourable to art. (Bosanquet 1886, 18-19)

The issue at stake in Hegel's thesis of the end of art is not the trivial question of whether there are still works of art in the current world or not; rather, the problem under discussion is whether the arts are still essential to human forms of life. Paolo D'Angelo has pointed out that the real issue at stake in Hegel's claim is not art's existence but its function and vitality within the current human 
word (D'Angelo 2007, XXXI). It cannot be denied that Dewey's vocabulary on "the function of art" (LW 10,17 and 330), "esthetic hunger" (LW 10, 12 and 345) as well as on human and esthetic "needs" (LW 10, 37, 331) and "satisfaction" (LW 10, 37 ) is primarily connected to a basically naturalistic attitude towards the arts and the aesthetic within experience. Nonetheless, a much more complex reading of Dewey's claims is to interpret them as also having an originally Hegelian background.

Hence, what does it mean for Dewey that the arts belong to our past? It means that the compartmental or museum conception of art, that is our current considering art as a separate realm alien to ordinary work and practical life conditions, represents a disruptive change with respect to any previous form of embedment of the arts within societal life. The end of art in a Deweyan sense means the isolation of art in the context of a highly industrialized society and of people's difficulties in enjoying the innovative life conditions brought about by scientific and technical changes (LW 10, 339 and ff.). It also means the incapacity of fine arts or highbrow culture to satisfy the aesthetic needs of most people (LW 10, 12), their failure in "affecting the imagination and emotions of man" (LW 10, 346). If the man and woman on the street can no longer immediately identify with the products of the art world (Gadamer 1985, 44), they will find satisfaction in other artistic activities, broadly speaking - movies and Jazz music, that were perceived as mass art in Dewey's time, but also "newspaper accounts of love-nests, murders and exploits of bandits" (LW 10 11-12), which were viewed by him negatively not because of any intellectualist reasons, but for the political consequences they might entail. It could also be argued that the philosophical denial of the kind of immediate recognition of people in the products of so-called cultural industry nourishes a form of "false consciousness" and ingenuity about alleged artistic autonomy. The independence of Art (with a capital A and in the singular) should be labeled as something merely "abstract" from a Hegelian point of view because it isolates an individual part from the broader process in which it takes place: the autonomy of the art world that has come to be affirmed in Western Europe and North America in modern times is illegitimate if it is assumed to apply to any form of artistic practice and aesthetic experience in every culture and age, as well as every artistic or aesthetic behavior characterizing people within Western culture.

Nonetheless, the Pragmatist mark is still evident here in the form of a melioristic and non-naïve attitude which characterizes even Dewey's strongest criticism of the state of the arts in current times:

[...] it is safe to say that a philosophy of art is sterilized unless it makes us aware of the function of art in relation to other modes of experience, and 
unless it indicates why this function is so inadequately realized, and unless it suggests the conditions under which the office should be successfully performed. (LW 10, 17)

Dewey did not stop at the acknowledgment that a certain mode of experiencing the arts as an integral part of a shared ethos had come to an end in Western societies, because of the process of art becoming separate and autonomous from other fields of meaning. Instead, he argued in favor of a militant philosophy seeking to explore alternatives and solutions to the current state of artistic practices. Here, again, we can see that an originally Hegelian insight is merged with a strong social and political claim, as well as with a conception of artistic behaviors as deeply rooted in the natural and naturally cultural needs and wants of human beings.

Ultimately, I would argue that Hegel's legacy in Dewey's pragmatist aesthetics should not be underestimated, but must rather be considered one particular source of inspiration among a range of sources that nourished Dewey's passionate concern for the place and functions of artistic practices within human life.

\section{Acknowledgements}

This article is based on research I was able to carry out at the Special Collection Center of the Morris Library at Carbondale (Southern Illinois University) primarily thanks to the generous support of Kenneth Stikkers, to whom I am strongly grateful. I also thank the head of the Department of Philosophy at Southern Illinois University, Anthony Steinbock, for hosting me as visiting professor for some time in Spring 2019. I am further indebted to Larry Hickman, who provided some important feedback on my research. Finally, many thanks to Nicholas Lee Guardiano, whose help in guiding me through the many books, papers and other material at the Special Collection Center of the Morris Library was crucial for my inquiry.

\section{Works Cited}

Alexander, Thomas M.John Dewey's Theory of Art, Experience and Nature. The Horizons of Feeling. New York: Suny, 1987.

Alexander, Thomas M. "Comments on James Good, A Search for Unity in Diversity", Transactions of the Charles S. Peirce Society, 44/4, 2008, pp. 563-568. 
Boas, Franz. The Mind of the Primitive Man, New York: Macmillan and Co., 1911.

Bosanquet, Bernard. The Introduction to Hegel's Philosophy of Fine Art. Translated from the German with notes and Prefatory Essay by Bernard Bosanquet, London: Paul Kegan 1886.

Bryant, William McKendree. The Philosophy of Art:Being the Second Part of Hegel's Aesthetik, in which are unfolded historically the three great fundamental phases of the art-activity of the world, New York: Appleton \& Co. 1879.

Caird, Edward. Hegel, Edinburgh: Blackwood and Sons, 1883.

Calcaterra, Rosa Maria. "Cristianesimo, hegelismo, darwinismo". In Idee concrete. Percorsi nella filosofia di John Dewey. Genova: Marietti, 2011, pp. 22-33.

Campeotto, Fabio, Viale, Claudio Marcelo. “Barnes' influence on John Dewey's Aesthetics: a preliminary approach. Cognitio, 19/2, 2018, pp. 227-241.

Carritt, Edgard Frederik. Philosophies of Beauty. From Socrates to Robert Bridges being the Source of Aesthetic Theory, New York, London, Toronto: Oxford U.P., 1931.

Clegg, Jerry C. On Genius: Affirmation and Denial from Schopenhauer to Wittgenstein, New York-Washington-San Francisco-Berna-Francoforte-Berlino-Vienna: Peter Lang, 1994.

Colonnello, Pio, Spadafora, Giuseppe. Croce e Dewey. Cinquanta anni dopo. Napoli: Bibliopolis, 2002.

Cometti, Jean-Pierre. La démocratie radicale. Lire John Dewey, Paris: Gallimard 2016.

D’Angelo, Paolo. "Introduzione". In Hegel, Georg Wilhelm Friedrich. Lezioni di estetica. Corso del 1823, edited by Paolo D'Angelo. Roma-Bari: Laterza, 2000, pp. $\mathrm{v}-\mathrm{xxxvi}$.

Dewey, John. "The Psychological Standpoint". In $E W$ 1, Carbondale and Edwardsville: Southern Illinois U.P., 1969, pp. 116-121.

Dewey, John. "Psychology as Philosophic Method". In EW 1, Carbondale and Edwardsville: Southern Illinois U.P., 1969, pp. 122-143.

Dewey, John. Psychology. EW 2, Carbondale and Edwardsville: Southern Illinois U.P., 1967.

Dewey, John. "Green's Theory of the Moral Motive". In Ew 3, Carbondale and Edwardsville: Southern Illinois U.P., 1969, pp. 155-174.

Dewey, John. “The Theory of Emotion”. In $E$ W 4, Carbondale \& Edwardsville: Southern Illinois U.P., 1971, 152-188.

Dewey, John. "Review of $A$ History of Aesthetics, by Bernard Bosanquet". In $E W 4$, Carbondale and Edwardsville: Southern Illinois U.P., 1971, pp. 189-197.

Dewey, John. "The Reflex-Arc Concept in Psychology". In EW 5, Carbondale and Edwardsville: Southern Illinois U.P., 1972, pp. 96-109.

Dewey, John. Human Nature and Conduct. MW14, Carbondale and Edwardsville: Southern Illinois U.P., 1988. 
Dewey, John. Experience and Nature. $L W$ 1, Carbondale and Edwardsville: Southern Illinois U.P., 1988.

Dewey, John. "The Public and its Problems". $L W$ 2, Carbondale and Edwardsville: Southern Illinois U.P., 1984, pp. 235-372.

Dewey, John. "Individualism Old and New". In LW 5, Carbondale and Edwardsville: Southern Illinois U.P., 1988, pp. 41-123.

Dewey, John. "From Absolutism to Experimentalism". In LW 5, Carbondale and Edwardsville: Southern Illinois U.P., 1988, pp. 147-161.

Dewey, John. Art as Experience. $L W$ 10, Carbondale and Edwardsville: Southern Illinois U.P., 1989 .

Dewey, John. The Correspondence of John Dewey, 1871-1952 (I-III). Electronic Edition. Charlottesville: InteLex Corporation, 1999.

Dreon, Roberta. Fuori dalla torre d'avorio. L'estetica inclusiva di John Dewey oggi, Genova-Milano: Marietti 2012. Transalted into French as Sortir de la tour d'voire. L'esthétique inclusive de John Dewey aujourd'hui, Paris: Questions thèoriques, 2017.

Dreon, Roberta. "How to do different things with words: why Dewey's aesthetics is peculiar". Pragmatism Today, 4, 2013, pp. 74-84.

Dreon Roberta. "Aesthetic Issues in Human Emancipation. Between Dewey and Marcuse". Pragmatism Today, 6, 2015, pp. 74-85.

Dreon, Roberta. "L'esthétique, l'artistique et l'humain: continuité et différence entre art et expérience chez Dewey". In Après l'art comme expérience. Esthétique et politique aujourd'hui à la lumière de John Dewey, edited by Jean-Pierre Cometti and Giovanni Matteucci, Paris: Questions téoriques, 2017, pp. 57-91.

Dreon, Roberta. 'La 'distincion de lo estetico' en clave pragmatista. Dewey, Gadamer y la antropologia de la cultura”. In John Dewey: una estetica de este mundo, edited by Luis Arenas, Ramon Del Castillo, Angel M. Faerna, Zaragoza: Prensas de la Univesidad de Zaragoza, 2018, pp. 213-234.

Gadamer, Hans-Georg. Truth and Method. London, New York: Continuum, 1989.

Gadamer, Hans-Georg. "Ende der Kunst? Von Hegels Lehre vom Vergangenheitscharakter der Kunst bis zur Anti-Kunst von Heute”. In Gesammelte Werke 8, Tübingen: Mohr, 1993, pp. 206-220.

Garroni, Emilio. Estetica ed epistemologia: riflessioni sulla Critica del giudizio. Roma: Bulzoni, 1976.

Gethmann-Siefert, Annemarie. Die Funktion der Kunst in der Geschichte. Untersuchungen zu Hegels Ästhetik, Bonn: Bouvier, 1984.

Gethmann-Siefert, Annemarie. "Nuove fonti e nuove interpretazioni dell'estetica di Hegel”. In L'estetica di Hegel, edited by Mario Farina and Roberto Siani. Bologna: il Mulino, 2014, pp. 13-31. 
Givone, Sergio. “Introduzione”. In Hegel, Georg Wilhelm Friedrich. Estetica. Torino: Einaudi, 1997, pp. xxi-xxxv.

Good, James A. “The Hegelian Roots of Dewey's Pragmatism”. In Pragmatism and Education, edited by Daniel Tröhler and Jürgen Oelkers. Rotterdam: Sense Publishers, 2005, pp. 11-26.

Good, James A. "John Dewey's 'Permanent Hegelian Deposit' and the Exigencies of War". Journal of the History of Philosophy, 44/2, 2006a, pp. 293-313.

Good, James A. A Search for Unity in Diversity. The "Permanent Hegelian Deposit" in the Philosophy of John Dewey. Lanham, Boulder, New York, Toronto, Oxford: Lexington Books, 2006b.

Hegel, Georg Wilhelm Friedrich. The Phenomenology of Spirit. Cambridge: Cambridge U.P., 2018.

Hegel, Georg Wilhelm Friedrich. The Philosophy of Fine Art, translated by F.B.P. Osmaston, Oxford: Clarendon U.P., 1920.

Hegel, Georg Wilhelm Friedrich. Aesthetics. Lectures on Fine Art, translated by Thomas Malcolm Knox, Oxford: Clarendon U.P., 1975.

Hickman, Larry A. "Dewey's Hegel: A Search for Unity in Diversity, or Diversity as the Growth of Unity?", Transactions of the Charles S. Peirce Society, 44/4, 2008, pp. 569-576.

Kandinsky, Wassily. Concerning the Spiritual in Art. New York: Dover, 1977.

Kant, Immanuel. Critique of the Power of Judgment, Cambridge: Cambridge University Press, 2000.

Kedney, John Steinfort. Hegel's Aesthetics. A Critical Disposition, Chicago: Griggs \& Co. 1885 .

Kristeller, Paul Oskar. "The Modern System of the Arts (I)“. Journal of the History of Ideas, 12, 1951, pp. 496-527.

Kristeller, Paul Oskar. "The Modern System of the Arts (II)“. Journal of the History of Ideas, 13, 1952, pp. 17-46.

James, William. The Principles of Psychology, Cambridge and London: Harvard U.P., 1981.

Levine, Steven. "Hegel, Dewey, and Habits". British Journal of the History of Philosophy, 23/4, 2015, pp. 632-656.

Marcuse, Herbert. Eros and Civilization. A Philosophical Inquiry into Freud. Boston: Beacon, 1966.

Margolis, Joseph. Reinventing Pragmatism. American Philosophy at the End of the Twentieth Century, Ithaca and London: Cornell University Press, 2002.

Mead, George Herbert. "The Nature of Aesthetic Experience". The InternationalJournal of Ethics, 36/4, pp. 382-393.

Montani, Pietro. Estetica ed ermeneutica: senso, contingenza, verità. Roma-Bari: Laterza, 1996. 
Morse, Donald J. Faith in Life. John Dewey's Early Philosophy. New York: Fordham U.P., 2011.

Pinkard, Terry. "Symbolic, Classic, and Romantic Art". In Hegel and the Arts, edited by Stephen Houlgate. Evanston: Northwestern U.P. 2007a, pp. 3-28.

Pinkard, Terry. "Was Pragmatism the Successor of Idealism?". In New Pragmatists, edited by Cheryl Misak, Oxford: Oxford U.P., 2007b, pp. 142-168.

Pippin, Robert. "The Absence of Aesthetics in Hegel's Aesthetics”. In The Cambridge Companion to Hegel and Nineteenth Century Philosophy, edited by Frederick C. Beiser. Cambridge: Cambridge U.P., 2008, pp. 394-418.

Poggi, Stefano. L'anima e i cristallo. Alle radici dell'arte astratta. Bologna: il Mulino, 2014.

Proulx Jeremy. "Nature, Judgment and Art: Kant and the Problem of Genius". Kant Studies on line, 31, 2011, pp. 27-53.

Rosenkranz, Karl. Georg Wilhelm Friedrich Hegel's Leben, Berlin: Duncker und Humblot, 1844 .

Särkelä, Arvi, "Immanent Critique as Self-Transformative Practice: Hegel, Dewey, and Contemporary Critical Theory". Journal of Speculative Philosophy, 31/2, pp. 218-230.

Schopenhauer, Arthur. The World as Will and Presentation, New York: Longman, 2008.

Seoane, Julio. "La experiencia estética como fondamento de la democracia deweyana". In John Dewey: una estetica de este mundo, edited by Luis Arenas, Ramon Del Castillo, Angel M. Faerna, Zaragoza: Prensas de la Univesidad de Zaragoza, pp. 237-261.

Shiner, Larry. The Invention of Art. A Cultural History. Chicago: Chicago U.P., 2001.

Shook, John R., Dewey's Empirical Theory of Knowledge and Reality. Nashville: Vanderbilt U.P., 2000.

Shook, John R., Good, James A.John Dewey's Philosophy of the Spirit. With the 1897 Lecture on Hegel. New York: Fordham U.P., 2010.

Shusterman, Richard. Pragmatist Aesthetics. Living Beauty, Rethinking Art. Lanham, Boulder, New York, Toronto, Oxford: Rowman and Littlefield Publishers, 2000.

Skelton, Anthony. “Carritt, E.F.”. In International Enciclopedia of Ethics, edited by Hugh LaFollette, Hoboken: Wiley-Blackwell, 2016.

Skowroński, Krzysztof Piotr. "Politica y estética en el pragmatismo de John Dewey". In John Dewey: una estetica de este mundo, edited by Luis Arenas, Ramon Del Castillo, Angel M. Faerna, Zaragoza: Prensas de la Univesidad de Zaragoza, pp. 263-281.

Testa, Italo. "Dewey, Second Nature, Social Criticism, and the Hegelian Heritage”. European Journal of Pragmatism and American Philosophy, IX/I, 2017, pp. 1-23.

Tiles, James “The Fortune of 'Functionalism”. In Dewey Reconfigured. Essays on Deweyan Pragmatism, edited by Casey Haskins and David I. Seiple, Albany: State University of New York Press, 1999, pp. 39-61.

Westbrook, Robert B. John Dewey and American Democracy, Ithaca and London: Cornell U.P., 1991. 